multiples of sister and homologous chromosomes with no formation of chiasmata.

Considerable indirect evidence favours the interpretation that these divisions are somatic reduction divisions. Decisive evidence is being sought by attempting to observe the process in the living organism.

$$
\begin{gathered}
\text { Johns Hopkins University, } \\
\text { and } \\
\text { Woodstock College, } \\
\text { Maryland. } \\
\text { March 10. }
\end{gathered}
$$

1 cf. Trager, W., J. Exp. Zool., 76, 467 (1937).

2 Berger, C. A., Anat. Rec., 67, Supp., 1, 63 (1936); Berger, C. A., Genetics, 23, 140 (1938); Berger, C. A., Carnegie Inst. of Wash., Contrib. to Embryol., 27 (in the Press).

\section{Absorption of Growth-Promoting Substances by Cuttings}

Авочт two years ago a batch of leafless cuttings of Bougainvillea (var. Mrs. Louis Walthen) was received at these laboratories for propagation. They were planted in our usual propagators. The majority threw out small shoots but there was no callussing or root development. After eighteen months it was decided to try the effect of a proprietary root growthpromoting substance. The cuttings still alive were treated in the normal way, that is, by immersion of the basal ends in a dilute solution for eighteen hours. However, no callussing or rooting took place and it is assumed that this was due to lack of transpiration in the cuttings, which were leafless when treated.

Finally it was decided to try the effect of forcing the growth-promoting substance into the cuttings now almost exhausted of food reserves. The ends of the cuttings were cut off to expose fresh surfaces. The lower ends were submerged to a depth of one inch in the solution contained in a vacuum desiccator which was exhausted until a strong stream of bubbles emerged from the bottom end of each cutting. On breaking the vacuum the solution was forced into the submerged ends. Two or three months after replanting the cuttings, 90 per cent rooted and are now healthy plants.

The experiment was not planned as a test of the growth-promoting substance, but was made in a final attempt to save the last remaining cuttings of a variety new to Kenya. So striking have been the results that the suggestion is put forward that possibly failure to secure rooting with winter cuttings of deciduous plants after treatment with various growth-promoting substances has been due to nonabsorption, or to the absorption of too little of the material by the leafless cuttings.

T. H. JACKSON.

Scott Agricultural Laboratories,

Department of Agriculture,

P.O. Box 323,

Nairobi, Kenya.

March 22

\section{Probable Fossil Hail Impressions in Natal Coal Measures (Middle Ecca Series)}

DURING the course of a geological survey of the Verulum district, Natal ${ }^{1}$, some peculiar little depressions were noticed on the upper surfaces of freshly exposed slabs of lower Middle Ecca (Permian) sandy shales occurring in a small road-metal quarry situated on the main road between Verulum and Tongaat, a little north of the Shortlands Hotel. The depressions appeared to be confined to a single horizon which, owing to the lack of exposures, could not be traced beyond the confines of the quarry.

The depressions, which are circular to slightly elliptical in outline, are bounded by slightly raised edges. In size they are remarkably uniform, averaging about $14 \mathrm{~mm}$. in diameter and $5 \mathrm{~mm}$. in depth, while in shape casts showed that they are slightly assymmetric, the steeper sides being usually similarly orientated.

Specimens cut perpendicularly to the bedding revealed that the laminæ immediately under the depressions were arched down as though the latter had been caused by blows. Their casts in the overlying horizon were found to be slightly coarser grained than the bounding layers and invariably plano-convex in shape.

It has been indicated by Twenhofel ${ }^{2}$ that the maximum depth of rain-drop impressions appears to be $3 \mathrm{~mm}$. and their maximum width $12 \mathrm{~mm}$. It would seem, therefore, that some other natural origin should be postulated for these depressions. Their character seems to suggest that they were caused by the impact of hailstones, since their relatively great depths in proportion to their diameters eliminates the possibility of their being splash impressions.

Twenhofel ${ }^{2}$ also figures artificial hail-impressions in mud which are characterized by very steep sides and relatively great depths. Preliminary observations made during actual hailstorms and experiments made by dropping ice spheres indicate, however, that even in highly plastic muds, a layer of water only a few millimetres in thickness over the surface of the mud suffices to modify the effects considerably-shallower and more regular plano-convex depressions resulting. Futhermore, if the hail falls on exposed sand or sandy mud, shallower depressions result, provided that other factors such as the size, shape and velocity of the stones remain constant. In the case of only slightly plastic moist sands, secondary minor depressions, either adjacent to or overlapping the major direct ones, are formed owing to the bouncing of the hailstones.

In the present area the unconsolidated material was a sandy mud which, as fossil rain-prints, etc., noted in other portions of the Verulum area indicate, was on occasion exposed to sub-zerial conditions. Incidentally, depressions identical in appearance with those on the sandy shales were produced by dropping small rounded hailstones from a height of $15 \mathrm{ft}$. into a sandy mud which was covered by a $2 \mathrm{~mm}$. film of water.

With one exception ${ }^{3}$, these would appear to be the first impressions tentatively attributed to the action of hail which have been recorded from the whole geological column. The re-examination of reported 'rain print' localities in the light of experimental evidence would, however, appear to be desirable.

Geological Survey, Pretoria,

Union of South Africa.

${ }^{2}$ Kent, L. E., "The Geology of a Portion of Victoria County, Natal", Trans. Geol. Soc. S. Africa, 41, 1-36 (1938).

"Twenhofel, W. H., "Treatise on Sedimentation" (2nd Edition. 1932), p. 680 .

"Lyell, Sir Charles, "On Fossil Rain-marks of the Recent, Triassic, and Carboniferous Periods", Quart. J. Geol. Soc. Lond., 7, 243 (1851). 